\title{
RESEARCH PAPER \\ Available phosphorus in starter diets for meat-type quail
}

\author{
Renata Gomes de Oliveira1, Sandra R. Freitas Pinheiro ${ }^{1}$, Karen B. Goulart ${ }^{1}$, \\ Aldrin V. Pires ${ }^{1}$, Frederico de C. Figueiredo ${ }^{2}$, and Karoll A. Alfonso Torres- \\ Cordido $^{3}$ \\ ${ }^{1}$ Animal Science Department, Federal University of Vales do Jequitinhonha e Mucuri, Rodovia MG 367, n. \\ 5000 -Alto do Jacuba. Diamantina-MG, CEP 39100-000, Brazil. \\ ${ }^{2}$ Federal Institute of Espírito Santo, Campus Itapina BR 259, Km 70, Colatina-ES Brazil. \\ ${ }^{3}$ State University of Norte Fluminense, Av. Alberto Lamego n. 2000 Campos dos Goytacazes-RJ,CEP \\ 28013-602, Brazil.
}

\begin{abstract}
R.G. Oliveira, S.R.F. Pinheiro, K.B. Goulart, A.V. Pires, F.C. Figueiredo and K.A.A. Torres-Cordido. 2015. Available phosphorus in starter diets for meat-type quail. Cien. Inv. Agr. 42(1): 19-25. Phosphorus is an important mineral for optimum growth and bone mineralization and is considered the third most expensive nutrient in diets for nonruminants. An experiment was conducted to evaluate the available phosphorus requirements (AP) for meat-type quail in the starter phase (1 to 21 days old). One-day-old, unsexed European quail (375) from the LF1 lineage were used for the study and were housed in pens. The experiment had a completely randomized design, with five treatments $(0.13,0.23,0.33,0.43$ and $0.53 \%$ of AP), each of which included five replicates in 15 birds. Feed intake, weight gain, feed conversion ratio, and the tibial deposition of phosphorus, calcium, and ash were assessed. The AP levels influenced all studied variables. We calculated that levels of $0.381 \%$ AP or $0.12 \% \mathrm{AP}$ megacalorie of metabolizable energy ( $\% \mathrm{AP} / \mathrm{Mcal} \mathrm{ME})$ were best for bone quality related to high tibial ash deposition.
\end{abstract}

Key words: Calcium, bone growth, calcium/phosphorus ratio, quail.

\section{Introduction}

The Brazilian quail production is growing rapidly. The Brazilian Institute of Geography and Statistics (IBGE) recorded annual increases of $19.8 \%$ between 2009 and 2011 (Quintslr and Bolliger, 2012). According to the Brazilian Association of Animal Protein (ABPA), 5.56 million quail were slaughtered in 2013, which corresponded

Received June 18, 2014. Accepted March 15, 2014. Corresponding author: sandrazoot@yahoo.com.br to $74.13 \%$ of the national production of nonconventional types of poultry (i.e., not broilers and turkeys) (ABPA, 2014). However, the national production of specific lineages of meat-type quail is in development; therefore, research is required to optimize the genetic potential of the lineages (Barbieri et al., 2015). According to Teixeira et al. (2013a), it is necessary to establish meat-type quail breeding programs, to understand quail nutritional needs, and to development feeding programs aimed at improving the performance and carcass yield. 
Among the macrominerals that are provided in poultry feed, both phosphorus and calcium are important because of their contributions to optimal growth rates and bone mineralization. According to Underwood and Suttle (1999), phosphorus is the second-most abundant mineral in the composition of animal tissue, with $80 \%$ of phosphorus found in the bones and teeth and the remainder distributed among other tissues and fluids. Furthermore, phosphorus is essential for the formation of molecules, such as phospholipids in cell membranes, and the nucleic acids that are involved in the maintenance of osmotic and electrolytic balance. It is also essential for the use and transfer of energy, the transport of fats and the synthesis of amino acids and proteins, and it participates in the control of appetite and feed efficiency (Runho et al., 2001).

The sources of phosphorus are considered one of the most expensive ingredients in diets, following only energy and protein. This mineral is currently being researched because of its economical and physiological importance and its impact on the environment. Thus, much research has focused on decreasing phosphorus excretion in birds without compromising animal performance. However, the nutritional requirements of phosphorus that are used in the formulation of diets for meat-type quail have been extrapolated from studies in laying quail (Lima et al., 2009). Given the importance of phosphorus in animal feed, we conducted this research to evaluate the nutritional requirements of AP to obtain the optimal productive performance and mineral deposition in the bones of starter phase (from 1 to 21 days old) meat-type quail of the LF1 lineage.

\section{Materials and methods}

\section{Birds and experimental design}

The experiment was conducted in the Animal Science Department of the Federal University of Vales of Jequitinhonha and Mucuri (UFVJM) in Diamantina-Minas Gerais, Brazil, in 2010. Three hundred seventy-five 1-day-old, unsexed, LF1 meat-type quail (Coturnix coturnix coturnix) from the Quail Breeding Program at the UFVJM were used in the study. The experiment had a completely randomized design with five levels of AP $(0.13,0.23,0.33,0.43$ or $0.53 \%)$ in the diet and five replicates with 15 quail each. The birds were reared in $1.00 \times 0.70 \mathrm{~m}$ pens that were placed on a litter floor (wood shavings, approximately 5 cm deep), and each pen had a manual feeder with cup drinkers and a gas brooder. Only natural light was used, and no specific light program was followed. The maximum and minimum environmental temperatures were registered with thermometers that were placed at different sites in the room.

\section{Treatments}

The quail were fed experimental diets, which consisted of corn and soybean meal, and these diets were formulated according to nutritional requirements, except for the AP (Table 1), and in agreement with the composition of ingredients in Rostagno et al. (2005). Quail were fed ad libitum throughout the experimental period.

\section{Performance and bone quality}

Performance variables such as feed intake (g), weight gain (g) and feed conversion ratio (feed intake/weight gain) were determined. The rates of mortality were used as a factor of feed intake correction. The tibial percentage of calcium, phosphorus and ash were considered variables of bone quality. At 21 days, three quail from each replicate were fasted for five hours and then killed by cervical dislocation. The two tibias of each bird were dissected and boiled in distilled water for five minutes. Fibula and cartilage were also removed. The tibias were identified with aluminum plates, immersed in petroleum ether for 48 hours, and dried in an oven with forced ventilation at 60 ${ }^{\circ} \mathrm{C}$ for $48 \mathrm{~h}$. Then, the bones were ground up in a 
Table 1. Percentage composition and calculated analysis of experimental starter diets for meat-type quail (1 to 21 days old).

\begin{tabular}{|c|c|c|c|c|c|}
\hline \multirow[b]{2}{*}{ Treatments } & \multicolumn{5}{|c|}{ Available phosphorus (\%) } \\
\hline & 0.13 & 0.23 & 0.33 & 0.43 & 0.53 \\
\hline \multicolumn{6}{|l|}{ Ingredients } \\
\hline Yellow corn & 51.115 & 51.115 & 51.115 & 51.115 & 51.115 \\
\hline Soybean meal (45\%) & 43.168 & 43.168 & 43.168 & 43.168 & 43.168 \\
\hline Soybean oil & 2.101 & 2.101 & 2.101 & 2.101 & 2.101 \\
\hline Salt & 0.330 & 0.330 & 0.330 & 0.330 & 0.330 \\
\hline L-lysine $\mathrm{HCl}$ & 0.119 & 0.119 & 0.119 & 0.119 & 0.119 \\
\hline DL-methionine & 0.171 & 0.171 & 0.171 & 0.171 & 0.171 \\
\hline Trace mineral and vitamins premix ${ }^{1}$ & 0.200 & 0.200 & 0.200 & 0.200 & 0.200 \\
\hline Calcium phosphate & 0.062 & 0.603 & 1.145 & 1.684 & 2.224 \\
\hline Limestone & 1.734 & 1.385 & 1.035 & 0.686 & 0.338 \\
\hline Inert $^{2}$ & 1.000 & 0.810 & 0.617 & 0.425 & 0.234 \\
\hline Total & 100.00 & 100.00 & 100.00 & 100.00 & 100.00 \\
\hline \multicolumn{6}{|l|}{ Composition calculated } \\
\hline Metabolizable energy $\left(\mathrm{kcal} \mathrm{kg}^{-1}\right)$ & 2.900 & 2.900 & 2.900 & 2.900 & 2.900 \\
\hline Crude protein $(\%)$ & 24.00 & 2400 & 24.00 & 24.00 & 24.00 \\
\hline Available phosphorus (\%) & 0.130 & 0.230 & 0.330 & 0.430 & 0.530 \\
\hline Total phosphorus (\%) & 0.382 & 0.482 & 0.582 & 0.682 & 0.782 \\
\hline Calcium (\%) & 0.800 & 0.800 & 0.800 & 0.800 & 0.800 \\
\hline Sodium $(\%)$ & 0.150 & 0.150 & 0.150 & 0.150 & 0.150 \\
\hline Digestible methionine (\%) & 0.500 & 0.500 & 0.500 & 0.500 & 0.500 \\
\hline Digestible methionine + cystine (\%) & 0.808 & 0.808 & 0.808 & 0.808 & 0.808 \\
\hline Digestible lysine (\%) & 1.300 & 1.300 & 1.300 & 1.300 & 1.300 \\
\hline Digestible threonine (\%) & 0.877 & 0.877 & 0.877 & 0.877 & 0.877 \\
\hline Digestible tryptophan (\%) & 0.274 & 0.274 & 0.274 & 0.274 & 0.274 \\
\hline
\end{tabular}

${ }^{1}$ Provided per kg product: vitamin A $1700 \mathrm{UI}$; vitamin B1 $250 \mathrm{mg}$; vitamin B12 $2500 \mathrm{mg}$; vitamin B2 $1000 \mathrm{mg}$; vitamin B6 500 mg; vitamin D3 375,000 UI; vitamin E 3000 UI; vitamin K3 400 mg; folic acid 175 mg; pantothenic acid $2500 \mathrm{mg}$; biotin $3.75 \mathrm{mg}$; choline $37.5 \mathrm{~g}$; niacin $7500 \mathrm{mg}$; bacitracin zinc $13.75 \mathrm{~g}$; salinomycin $16.5 \mathrm{~g}$; BHT $1000 \mathrm{mg}$; Cu 2500 mg; Fe 12.5 g; I 212.5 mg; Mn 17.5 g; Se 75 mg; Zn 15 g.

${ }^{2}$ Clean sand.

ball mill. The analyses were made in the Animal Nutrition Laboratory at the Animal Science Department of the UFVJM according to the methods of Silva and Queiroz (2002), and the results were expressed as defatted dry matter.

\section{Statistical analysis}

The data from the performance variables and bone composition were submitted to ANOVA after assumptions were met. The AP levels were unfolded in linear and quadratic effects regression analysis. An estimate of the AP levels was obtained using the "Linear Response Plateau" (LRP) and/or quadratic models. To check the fit of the models, the sum of the squares of the deviations, the significance of the $\mathrm{F}$ test and the determination coefficients were considered. To avoid the occurrence of high (overestimated) and low (underestimated) levels, where an adjustment of both models was possible, the optimal level was estimated by the first intersection of the quadratic equation with the plateau of the LRP, as described by Sakomura 
and Rostagno (2007). Statistical analyses were performed using the computer program SAEG (Sistema para Análises Estatísticas e Genéticas, Fundação Arthur Bernardes, Universidade Federal de Viçosa-MG, 2004), and significance was observed at the level of $5 \%(\mathrm{P} \leq 0.05)$.

\section{Results and discussion}

The feed intake (FI) was affected $(\mathrm{P} \leq 0.01)$ by the AP levels (Table 2). The settings for the linear ( $\mathrm{FI}=$ $\left.187.45+132.02 \mathrm{AP}, \mathrm{R}^{2}=0.64\right)$, quadratic $(\mathrm{FI}=$ $\left.125.914+588.865 \mathrm{AP}-692.19 \mathrm{AP}^{2}, \mathrm{R}^{2}=0.88\right)$ and LRP functions $(\mathrm{FI}=246.90+366.10(0.288-$ AP), $R^{2}=0.94$ ) were verified. The estimates from the LRP and quadratic functions were $0.288 \%$ and $0.425 \%$ of AP, respectively. The value from the intersection of the quadratic and LRP functions was $0.347 \%$ AP in the experimental diet or $0.12 \%$ AP/Mcal ME. Phosphorus is an element of adenosine triphosphate (ATP), a molecule that stores energy in the phosphate bonds for several biological processes. Thus, a diet deficient in phosphorus impairs ATP formation and leads to disturbances in the metabolism of energy and, consequently, to weight loss and a reduction in production (McDowell, 1992; Pinheiro et al., 2011). In this experiment, the lowest feed intake and weight gain were obtained at the $0.13 \% \mathrm{AP}$ level; thus, this level led to a nutritional deficiency of phosphorus in the meat-type quail (C. coturnix coturnix) lineage LF1. In contrast, we observed that high levels of AP inclusion (0.53\%) led to a discrete decline in feed intake. Similarly, Teixeira et al. (2013b) observed that $0.5 \%$ AP inclusion led to a lower feed intake than did $0.4 \%$ AP inclusion in broilers' diets (22 to 42 days old). However, Fassani et al. (2007) verified that meat-type quail had a higher feed intake when they were fed with $0.48 \%(0.165 \% /$ Mcal ME) of AP in the diet until 21 days of age, but that value was estimated using a quadratic model, which often overestimates the nutrients (Sakomura and Rostagno, 2007). Meanwhile, Mello et al. (2012) demonstrated the importance of maintaining the Ca:AP relationship. They evaluated the AP needs for growing broilers when the Ca:AP relationship was constant and observed that feed intake was not affected by the AP levels. The settings for the LRP $(\mathrm{P} \leq 0.01)$ and quadratic $(\mathrm{P} \leq 0.05)$ models that were used to test the weight gain (WG) results were also verified. The estimates of AP obtained were $0.229 \%$, using the LRP model with the equation $\mathrm{WG}=110.80$ - 138.30 (0229 - AP), $\mathrm{R}^{2}=0.73$, and $0.374 \%$, using the quadratic model with the equation $\mathrm{WG}=$ $80,176+176.99 \mathrm{AP}-236.75 \mathrm{AP}^{2}, \mathrm{R}^{2}=0.60$. The optimal level of AP for maximum weight gain was estimated by the intersection of the quadratic equation and the plateau of LRP and was $0.272 \%$ AP, which corresponded to $0.094 \%$ AP/Mcal ME. The lowest AP level in the experimental diet $(0.13 \%$, deficient in phosphorus) led to a smaller weight gain compared with the estimated levels, which could also be justified by the lower feed intake that was observed.

Table 2. Feed intake (FI), weight gain (WG), feed:gain ratio (FC) (1 to 21 days), tibial calcium (TCa), tibial phosphorus (TP) and tibial ash (TAs) in meat-type quail (21 days old) fed experimental starter diets with different levels of available phosphorus.

\begin{tabular}{|c|c|c|c|c|c|c|c|}
\hline \multirow[b]{2}{*}{ Variable } & \multicolumn{5}{|c|}{ Available phosphorus (\%) } & \multirow[b]{2}{*}{$\mathrm{CV}^{1}(\%)$} & \multirow[b]{2}{*}{$\mathrm{Pr}^{2}$} \\
\hline & 0.13 & 0.23 & 0.33 & 0.43 & 0.53 & & \\
\hline FI $\left(\mathrm{g} \mathrm{Bird}^{-1}\right)$ & 189 & 225 & 254 & 236 & 248 & 5.23 & 0.01 \\
\hline WG $\left(\mathrm{g} \mathrm{Bird}^{-1}\right)$ & 97 & 111 & 116 & 105 & 110 & 8.29 & 0.04 \\
\hline $\mathrm{FC}$ & 1.942 & 2.035 & 2.194 & 2.253 & 2.268 & 8.43 & 0.04 \\
\hline $\mathrm{TCa}(\%)$ & 34.727 & 38.923 & 40.527 & 46.124 & 54.834 & 15.72 & 0.01 \\
\hline $\mathrm{TP}(\%)$ & 16.275 & 26.440 & 23.586 & 30.105 & 31.225 & 15.64 & 0.01 \\
\hline TAs $(\%)$ & 20.334 & 28.811 & 30.234 & 28.927 & 28.073 & 10.33 & 0.01 \\
\hline
\end{tabular}

${ }^{1} \mathrm{CV}=$ Coefficient of variation; ${ }^{2} \mathrm{Pr} .=$ Probability. 
After assessing the phosphorus requirement for broilers in the initial phase, Runho et al. (2001) reported that a diet deficient in phosphorus caused a severe reduction in the synthesis and release of growth hormone and thyroid hormones, primarily T3, and that, consequently, the birds showed lower feed intake and lower weight gain. In contrast, Silva et al. (2009) and Furlan et al. (2009) estimated that $0.41 \%$ AP was required to maximize the weight gain of meat-type quail at 14 days old, which was higher than the levels observed in this study. This divergence between our results and those of other authors may be due to differences in the age and genetic lineage, considering that there are many genetically different quail being marketed in Brazil; we used LF1 quail, which is a specific lineage. The heritability of phosphorus utilization is significant in Japanese quail, similar to that in broilers (Beck et al., 2014). Therefore, research is necessary to determine the specific nutritional requirements of each lineage.

The results of the feed conversion (FC), which was adjusted $(\mathrm{P} \leq 0.01)$ according to the increasing linear equations $\left(\mathrm{FC}=1.85+0.868 \mathrm{AP}, \mathrm{R}^{2}\right.$ $=0.92)$ and $\operatorname{LRP}(\mathrm{FC}=2261-1259$ (AP - 0.391), $\left.\mathrm{R}^{2}=0.99\right)$, were verified. However, the levels of AP required to maximize feed conversion, as provided by these settings, could not be verified and were thus not suitable for recommendation.

The relationship between all of the bone variables and the phosphorus levels increased linearly $(\mathrm{P} \leq 0.01)$. An increase in calcium deposition in the tibia (TCa) that was proportional to the increasing levels of available phosphorus was observed according to the following equation: $\mathrm{TCa}=27.379+47.416 \mathrm{AP}\left(\mathrm{R}^{2}=0.93\right)$. This result was in agreement with that of Silva et al. (2009), who increased the phosphorus content in the diets of 14-day-old meat-type quail and observed a linear increase in the deposition of calcium and phosphorus. This response would be justified because the absorption of phosphorus depends on the absorption of calcium. In the bird's starter phase, the bone tissue formation rate is faster than it is in other phases, and the deposition of calcium and phosphorus in the tibia is also greater (Pinheiro et al., 2011).

Increasing levels of phosphorus in the diets provided a greater deposition of phosphorus in the tibia (TP) $(\mathrm{P} \leq 0.01)$, according to the following equation: $\mathrm{TP}=15,599+30.893 \mathrm{AP}\left(\mathrm{R}^{2}=0.78\right)$. Brugalli et al. (1999) verified an increased content of phosphorus in the bones and bone ash of broilers that were fed with increasing levels of available phosphorus in the diet.

The ash content in the tibia (TAs) of quail increased in both the linear form (TAs $=22.129$ $\left.+15.594 \mathrm{AP}, \mathrm{R}^{2}=0.39\right)$ and quadratic form $\left(\mathrm{TAs}=8.546+116.438 \mathrm{AP}-152.794 \mathrm{AP} 2, \mathrm{R}^{2}=\right.$ $0.91)$ and was estimated to reach a maximum at the level of $0.381 \% \mathrm{AP}$ or $0.13 \% \mathrm{AP} / \mathrm{Mcal}$ ME. A similar result was observed by Silva et al. (2009), who reported that the best response in optimal bone density was obtained with $0.41 \%$ AP, which corresponded to $0.14 \%$ AP/ Mcal ME, in the diets of meat-type quail up to 14 days of age. Yan et al. (2003) estimated a level of $0.31 \%$ AP for the increased deposition in bone ash in broilers at 49 days of age, and they recommended this level as a good strategy for feeding chickens to provide the optimal deposition in bone ash and a decreased excretion of phosphorus in the manure, thereby reducing environmental pollution.

The dietary AP levels required to maximize bird performance are lower than those required to promote good bone quality in the starter phase of broilers (Brugalli et al., 1999; Runho et al., 2001). The results obtained in this work suggest that the above concept can also be applied when recommendations are made for feeding meat-type quail. However, we acknowledge that the AP levels were more important in ensuring the quality of bone formation than a greater weight was during the quail starter 
phase. From this point of view, we recommend a level of $0.381 \%$ or $0.12 \%$ AP/Mcal ME for better bone quality, which will maximize ash deposition in the tibia of meat-type quail that are 1 to 21 days old.

\section{Acknowledgements}

Thanks go to Fundação de Amparo à Pesquisa do Estado de Minas Gerais (FAPEMIG), Brazil, because it financed the Project and an undergraduate scholarship for the research.

\title{
Resumen
}

\begin{abstract}
R.G. Oliveira, S.R.F. Pinheiro, K.B. Goulart, A.V. Pires, F.C. Figueiredo y K.A.A. TorresCordido. 2015. Fósforo disponible en dietas para codornices de engorde en la fase inicial de cría. Cien. Inv. Agr. 42(1): 19-25. El fósforo es un mineral importante por ser necesario para la óptima tasa de crecimiento y para la mineralización ósea, siendo considerado como el tercer nutriente más caro en los concentrados para no rumiantes. Fue conducido un experimento para evaluar las exigencias de fósforo disponible (Pd) para codornices de engorde en la fase inicial de cría (1 a 21 días de edad). Se utilizaron 375 codornices europeas, linaje LF1, no sexadas, instaladas en compartimientos. El delineamiento experimental utilizado fue enteramente al azar, siendo los tratamientos constituidos por cinco niveles de $\mathrm{Pd}(0,13 ; 0,23 ; 0,33 ; 0,43$ y $0,53 \%)$ cada tratamiento contó con cinco repeticiones de 15 aves por repetición. Se evaluó el consumo de concentrado, la ganancia de peso, la conversión alimenticia y la deposición de fósforo, calcio y cenizas en las tibias. Se observó que los niveles de Pd estudiados influenciaron todas las variables analizadas. Fue calculado el nivel de $0,381 \%$ de Pd o 0,12\% de Pd/Megacaloría de Energía Metabolizable para obtener la mejor calidad ósea, porque permite maximizar la deposición de cenizas en la tibia de las codornices de engorde.
\end{abstract}

Palabras clave: Calcio, codornices, crecimiento óseo, relación calcio/fósforo.

\section{References}

ABPA-Associação Brasileira de Proteína Animal. União Brasileira de Avicultura. 2014. Relatório Anual. Available online at: http://www.ubabef.com.br/publicacoes $\mathrm{m}=75 \&$ date $=2014-03$ (Website accessed: March 2, 2015.

Beck, P., M. Rodehutscord, J. Bennewitz, and W. Bessei. 2014. A pilot study of the genetic variation of phosphorus utilization in young Japanese quail (Coturnix japonica), Poultry Science 93:1916-1921.

Brugalli, I., D.J. Silva, L.F.T. Albino, P.C. Gomes, H.S. Rostagno, and M.A. Silva. 1999. Exigência de fósforo disponível e efeito da granulometria na biodisponibilidade de fósforo da farinha de carne e osso para pintos de corte. Revista Brasileira de Zootecnia 28:1288-1296.
Fassani, E.J., T.C. Brigagão, A.V. Pires, and J. Moreira. 2007. Níveis de fósforo disponível em rações para codornas de corte na fase inicial de criação (um a 21 dias de idade). In: $44^{\text {a }}$ Reunião da Sociedade Brasileira de Zootecnia. CD-Room Memorias...: Universidade Estadual Paulista Campus de Jaboticabal. Jaboticabal- SP, Brazil.

Furlan, A.C., R.M. Silva, E.N. Martins, A.E. Murakami, A.P.S. Tom, A.S. Iwahashi, and G.A.D. Gonçalves. 2009. Exigência nutricional de cálcio e de fósforo de codornas de corte (Coturnix coturnix sp) em fase final de crescimento (15 a 35 dias de idade). In: $45^{\text {a }}$ Reunião da Sociedade Brasileira de Zootecnia. CD-Room Memorias...: Universidade Federal de Lavras. Lavras-MG, Brazil.

Lima, R.B., J.H.V. Silva, D.F. Lima, P.B. Lacerda, R.A. Santos, E.P. Saraiva, and J. Jordão Filho. 
2009. Características do crescimento corporal de codornas japonesas e européias. In: $46^{\mathrm{a}}$ Reunião da Sociedade Brasileira de Zootecnia. CD-Room Memorias... Universidade Estadual de Maringá. Maringa-PR, Brazil.

McDowell, L.R. 1992. Calcium and phosphorus. In: Minerals in animal and human nutrition. San Diego: Academic Press. 524 pp.

Mello, H.H.C., P.C. Gomes, H.S. Rostagno, L.F.T. Albino, T.C. Rocha, R.L. Almeida, and A.A. Calderano. 2012. Dietary requirements of available phosphorus in growing broiler chickens at a constant calcium:available phosphorus ratio. Revista Brasileira de Zootecnia 41:2323-2328.

Pinheiro, S.R.F., N.K. Sakomura, D.C.N. Nascimento, L.R.B. Dourado, J.B.K. Fernandes, and M.C. Thomaz. 2011. Níveis nutricionais de fósforo disponível para aves de corte ISA Label criadas em semiconfinamento. Revista Brasileira de Zootecnia 40:361-369.

Quintslr, M.M.M, and F.P. Bolliger. 2012. Produção da Pecuária Municipal volume 392011 Brasil. Available online at: ftp://ftp.ibge.gov.br/Producao_Pecuaria/Producao_da_Pecuaria_Municipal/2011/ppm2011.pdf (Website accessed: March 2, 2015).

Rostagno, H.S, L.F.T. Albino, and J.L. Donzele. 2005. Tabelas brasileiras para aves e suínos (composição de alimentos e exigências nutricionais). Universidade Federal de Viçosa. ViçosaMG, Brazil. 186 pp.

Runho, R.C., P.C. Gomes, H.S. Rostagno, L.F.T. Albino, P.S. Lopes, and P.C. Pozza. 2001. Exigên- cia de fósforo disponível para frangos de corte machos e fêmeas de 1 a 21 dias de idade. Revista Brasileira de Zootecnia 30:187-196.

Sakomura, N.K., and H.S. Rostagno. 2007. Métodos de pesquisa em nutrição de monogástricos. $1^{\mathrm{a}} \mathrm{Ed}$. Jaboticabal-SP-Brazil: Fundação de Apoio à Pesquisa Ensino e Extensão da UNESP. 283 pp.

Silva, R.M., A.C. Furlan, A.P.S. Ton, E.N. Martins, C. Scherer, and A.E. Murakami. 2009. Exigências nutricionais de cálcio e fósforo de codornas de corte em crescimento. Revista Brasileira de Zootecnia 38:1509-1517.

Silva, D.J., and A.C. Queiroz, 2002. Análise de alimentos: métodos químicos e biológicos. 3 ed. Universidade Federal de Viçosa. Viçosa-MG, Brazil. 165 pp.

Teixeira, B.B., A.V. Pires, R.C. Veloso, F.M. Gonçalves, E.S.C. Drumond, and S.R.F. Pinheiro. 2013a. Desempenho de codornas de corte submetidas a diferentes níveis de proteína bruta e energia metabolizável. Ciência Rural 43:524-529.

Teixeira, E.N.M., J.H.V. Silva, C.C. Goulart, J. Jordão Filho, and M.L.G. Ribeiro. 2013b. Suplementação da fitase em rações com diferentes níveis de fósforo disponível para frangos de corte. Revista Ciência Agronômica 4:390-397.

Yan, F., J.H. Kersey, C.A. Fritts, and W. Waldroup. 2003. Phosphorus requirements of broiler chicks six to nine weeks of age as influenced by phytase supplementation. Poultry Science 82:294-300.

Underwood, E.J., and N.F. Suttle. 1999. The mineral nutrition of livestock. $3^{\mathrm{a}}$ ed. Wallingford: Cabi Publishing. CAB International, Wallingford. 614 pp. 
